\title{
Liberalism, Labour and State-Formation in Nineteenth-Century Europe
}

\author{
SIEP STUURMAN
}

Luebrert, Gregory M. Liberalism, Fascism, or Social Democracy. Social Classes and the Political Origins of Regimes in Interwar Europe. Oxford University Press, Oxford 1991. xi, 416 pp. £40.00. (Paperback: £15.00.)

BREuILLY, JoHN. Labour and Liberalism in Nineteenth-Century Europe. Essays in Comparative History. Manchester University Press, Manchester [etc.] 1992; distr. excl. in the USA and Canada by St. Martin's Press, New York. viii, 316 pp. $£ 40.00$.

Ever since Barrington Moore's Social Origins of Dictatorship and Democracy, students of European comparative history have been struggling with the problem of how to progress from the early modern period to the twentieth century. Barrington Moore "solved" the problem by moving directly from a structural analysis of the ancien régime to a description and analysis of twentieth-century political systems, quietly skipping almost the entire nineteenth century. The establishment of liberal democracy in Britain and France was accordingly related to the long-term consequences of seventeenth-and eighteenth-century revolutions, while the absence of an early modern revolution in Mitteleuropa is supposed to have induced the subsequent "revolutions from above" in the German lands and elsewhere." Another influential strand in the historiography regards the failure of the 1848 revolutions in central Europe as the critical bifurcation in the political history of Europe. The year 1848 was, to quote a justly famous passage from Trevelyan, "the turning point at which modern history failed to turn [ . . . It was the appointed hour, but the despotisms just succeeded in surviving it, and modernized their methods without altering their essential character."2

The discussion and critique of these determinist views has often focused on the conditions of liberal success in the nineteenth and early twentieth century, and especially on the comparison between Germany, France and Britain, which in its turn is linked to the Sonderweg debate in German historiography. The rest of Europe usually receives scant attention. An important opportunity for a broadly

' Barrington Moore jun., Social Origins of Dictatorship and Democracy (1966; Harmondsworth, 1974), pp. 435-141; sec too Theda Skocpol, States and Social Revolutions (Cambridgc, 1979), pp. 104-109, which also contrasts inter alia Prussia with France. Both Moore and Skocpol cmphasize the fusion between "feudalistic" agrarian labour relations, production for the market, and a military-bureaucratic state as the crucial determinant of Prussia's later development; both argue that early modern trends, culminating in the postNapolconic reforms, fixed the Prussian state in its authoritarian mould.

2 G. M. Trevelyan, British History in the Nineteenth Century and After (1922 and 1937; Harmondsworth, 1979), p. 287.

International Review of Social History 38 (1993), pp. 77-84 
based consideration of comparative arguments has thus been neglected. Gregory Luebbert, an American political scientist, has attempted to remedy this state of affairs. His book, published posthumously in 1991, offers a sustained comparative analysis of the trajectory of European politics from 1848 to the 1930s, discussing both major and minor countries. Apart from Britain, France and Germany, Luebbert provides substantial treatment of Sweden, Norway, Denmark, the Netherlands, Belgium, Switzerland, Italy and Spain.

According to Luebbert, there were three main results in the twentieth century of political developments in the nineteenth: liberal democracy, social democracy and Fascism. Moreover, Fascism is contrasted with "traditional dictatorship", a fourth type of political regime that eventually became prevalent in large parts of Eastern Europe. Luebbert wants to explain the various national trajectories that resulted in any of these four outcomes. The explanatory framework is provided by the interrelationship between societal cleavages and the formation of political movements in the context of the transition from elite to mass politics. The main cleavages Luebbert discusses are class, religion, language, regionalism, and urban and rural identities. Among these, class is highlighted, although the author nowhere implies that class interests dominated the political process. Instead, he starts from the "more modest assumption that socialist parties mainly aspired to act as agents of the working classes and that liberal parties mainly aspired to act as agents of the middle classes" (p. 6). The extent to which they succeeded in actually realizing these aspirations varied widely, as did their readiness and success in building inter-class coalitions. The explanation is mainly sought in the interaction between class politics and the other politically salient cleavages mentioned above.

Luebbert's analysis of nineteenth-century politics starts from the fact of liberal hegemony in Britain, France and Switzerland. These he calls the "liberal societies", as against the "a-liberal societies" predominating in the other parts of the Continent. Liberal hegemony is explained by the weakness of pre-industrial cleavages within the middle classes (to the extent that pre-industrial antagonisms in these three countries were important, Luebbert adds ambiguously, they served to enhance liberalism's appeal among the middle classes). The labour movement was then more or less co-opted into liberal politics; left-wing Liberals managed to build "Lib-Lab coalitions" which precluded or retarded the emergence of a vigorous and politically autonomous socialist movement. This political and cultural environment had enduring consequences for the political and psychological formation of working-class movements in liberal countries. As a result, they proved incapable of challenging the liberal order in the interwar period, thus sustaining centre-right regimes which frequently adopted anti-labour economic policies.

The major a-liberal societies were Germany, Austria, Sweden, Norway, Italy and Spain. In these countries parliamentary government developed much more slowly, and the state was dominated by conservative elites. The Liberals were unable to overcome the divisions within the middle classes, and they therefore remained weak. In these circumstances, a Lib-Lab strategy was unenticing for the emergent working-class movement and a dangerous experiment in the opinion of most middle-class observers. Left to its own devices, the labour movement developed strong, centralized trade unions and politically autonomous social democratic parties. Luebbert treats Denmark, the Netherlands and Belgium as variations on the a-liberal pattern: in those three cases the Liberals became well entrenched in the state, but liberal hegemony was eventually precluded by the rise 
of confessional movements (in Belgium, the Netherlands), or by the antagonism between town and country (Denmark). Therefore, no enduring Lib-Lab politics emerged, and the labour movement developed along social-democratic lines.

Luebbert emphasizes the similarities between the Scandinavian countries, Germany, Italy, and to a certain extent even Spain. In all of them an internally divided middle class faced a strong, autonomous socialist movement. After the introduction of universal male suffrage in the wake of the First World War, the old bourgeois parties, whether liberal or conservative, proved unable to form majority governments without the socialists and equally unable to establish a stable pattern of co-operation with the socialists. At the same time, the trade unions were well able to frustrate any free-market deflationary policy. In the steadily worsening economic climate of the inter-war years the combination of parliamentary immobilism and economic deadlock brought about an almost complete paralysis of the political process.

The deadlock was eventually broken, either by Fascism or by Scandinavian-style social democracy. There were of course enormous political and, above all, moral differences between these two resolutions of the inter-war political crisis. Yet they had something in common. Luebbert summarizes the similarities as "politics against markets": the state interfered with the market and, more specifically, with the labour market. An administered labour market emerged in which wage levels were set by political bargaining (in Scandinavia) or by administrative fiat (Fascism). In Fascist countries the administration of labour was coupled with totalitarian mobilization and infrastructural and military spending; in Scandinavia the new labour politics were linked to corporatism and the emergent welfare state. There remained, of course, the third group of "liberal-conservative" or "conservativeliberal" countries which pursued a policy of maintaining the free market supplemented with ad-hoc administrative measures.

Luebbert's explanation of the three divergent responses to the systemic crisis of the inter-war period focuses on the agrarian sector. The price controls of the war years, and the subsequent deflationary trend in the world economy, squeezed peasant incomes. The peasants and farmers in Britain, France, Switzerland, Belgium and the Netherlands were solidly integrated in liberal-conservative or confessional political blocs (Luebbert might have added that there were very few independent peasants in Britain anyway). In the other nations of Europe, however, the peasantry went adrift. It is Luebbert's contention that the peasantry rallied to the radical right in those countries where the socialists were successfully organizing agricultural labour, or even toyed with the idea of agricultural reform. Socialist gains in the agricultural sector thus contributed, ironically, to the eventual victory of the Fascists.

In Scandinavia this could not happen, not for want of effort on the part of the socialists but because of the simple fact that labourers in the countryside were already politically committed, integrated as they were in liberal or agrarian parties. This state of affairs was a precondition for the famous "historical pacts" the Scandinavian social democrats concluded with the agrarian parties in 1933 and 1935. The pacts combined public works and social security with financial and tax measures attuned to the needs of peasants.

Luebbert has given us an ambitious and courageous book, one whose detailed and sophisticated argument can hardly be done justice to in the space of this review article. The explanatory framework is consistently maintained throughout the 
entire analysis: the success and failure of political regimes is attributed to their ability to forge stable coalitions of mass movements and aspirations which are mainly (but not exclusively) explained in terms of class interests. There certainly is strength in consistency, and one must admire Luebbert's tenacity in sticking to his explanatory framework throughout the book without ever having recourse to ad-hoc hypotheses or escape clauses.

To say that a historical argument is sophisticated and consistent does not, however, imply that it is also entirely convincing. The general argument linking (later) socialist weakness to (earlier) liberal strength seems unexceptionable. The author is certainly right in pointing out the salience of the agricultural sector, and the urban/rural split, for the success of Scandinavian social democracy and to a certain extent for the emergence of Fascism as well. Luebbert's analysis of the causes of the strength of the Liberals seems to me rather less well-grounded, however.

My first doubts concern Luebbert's classification of "liberal" and "a-liberal" countries. His characterization of Belgium and the Netherlands as "a-liberal" strikes me as unconvincing. Both countries became parliamentary monarchies at an early stage, before or in $1848 .{ }^{3}$ Around 1870 , their regimes were not markedly less liberal than those of France and Switzerland. The electoral statistics provided by Luebbert himself show that even after the turn of the century the Dutch and Belgian (and, by that time, Danish) Liberals were doing little worse than their counterparts in France, or even Britain. Luebbert is certainly right to point to their electoral decline in the course of the decades after 1900, but he fails to compare it systematically with liberal decline elsewhere. Moreover, he underestimates the enduring vitality of liberal political culture in the judiciary, in intellectual life and within the upper classes more generally.

It would have been more convincing to regard Britain, France, Switzerland, the Netherlands and Belgium as varieties of a liberal regime, and Denmark as an in-between case. The a-liberal camp would then only include those countries where a non-parliamentary monarchy was able to remain in power during the half century following the 1848 revolutions: Sweden, Norway, Germany/Prussia, Austria, Spain and, as a borderline case, Italy. But the homogeneity of this group must not be overstated: Sweden and Norway were parliamentarized by endogenous forces in the decades around the turn of the century, while Germany and Austria stand out as regimes that were only parliamentarized after 1918, in the wake of military defeat. If we apply these modifications to Luebbert's portrayal of the patterns of liberal strength and weakness, the picture begins to look somewhat more traditional, in some respects resembling the older, more familiar dichotomy between the "Western" and "Eastern" patterns of European state-formation.

More than classification is at stake, however. Luebbert's explanation of the weakness and strength of liberalism has to be doubted, too. According to his analysis, the inability to overcome divisions within the middle classes and the unwillingness or incapacity to forge coalitions with artisans and peasants were the root causes of liberal failure. As so often, the German case is central to the argument. Luebbert makes much of the division within the German middle classes in 1848, and castigates the German liberals for neglecting the interests of the peasants. A recent study of the 1848 events in the Rhineland, however, demonstrates that there was a link between democratic movements in the towns and the

3uebbert himself states that Belgium and the Netherlands "most closely approximated the British-French-Swiss pattern of liberal hegemony" (p. 56). So why label them a-liberal? 
countryside in many German states, and that in these states the 1848-1849 movements did not "fail", but were conquered and crushed by an outside military power, the standing army of the Prussian state. The same argument applies in the case of the Prussian Konfliktzeit of the 1860s: Luebbert overstates the divisions in the liberal ranks, and minimizes the role of Bismarck's oblique but very credible threats of a military coup. Instead of the feeble performance of liberalism explaining Bismarck's successes, it was the other way around: Bismarck outmanœuvred the Liberals by winning two successive wars $(1864,1866)$ and thereby brought about a split in the Liberal Party. ${ }^{3}$ The passing of anti-socialist legislation in the 1870s divided the Liberals once more, again within an atmosphere of crisis which subsequently became an integral part of German political culture. ${ }^{6}$

The German example suggests that war and military power were at least as important as class coalitions in shaping political regimes. The importance of war as a force in state-formation has often been pointed out in studies of stateformation in early modern Europe.' Perhaps the nineteenth century has been observed too often from the British point of view, which has tended to regard it as having been a long period of peace from Waterloo to August 1914. War, however, was a crucial element in state-formation in central Europe, and in Italy and France as well. Military defeat was, for example, equally crucial to the birth of the French Third Republic as military triumph was to the making of Bismarckian Germany. Before 1870 the demise of the Second Empire was by no means a foregone conclusion. Moreover, the Third Republic was not wholeheartedly endorsed by certain groups within the French upper classes who seriously envisaged a "Bismarckian strategy", notably in the Boulangist episode and during the Dreyfus Affair. In France, however, the danger of a coup d'état from the right was counterbalanced by the credible menace, or at least the pervasive fear, of a revolutionary uprising from the left. The vigour of French liberalism was connected to a political culture that was shaped by enormously powerful historical memories, notably memories of successful revolutions. ${ }^{8}$ Late nineteenth-century German political culture, on the contrary, was suffused with the memory of a cumulative series of failed revolutions. This particular political culture, together with the development of the military machine as a state within the state, was one of the major preconditions for the eventual victory of Nazism; more so, one suspects, than the right-wing sympathies of the German peasantry in the inter-war period. In the final analysis, Luebbert systematically underestimates both the influence of political culture and of war and military power.

John Breuilly's new book, which brings together a number of valuable essays

\footnotetext{
4 Jonathan Sperber, Rhineland Radicals: The Democratic Movement and the Revolution of 1848-1849 (Princeton, 1991), pp. 476ff.

'See the detailed analysis in Wolfram Siemann, Gesellschaft im Aufbruch: Deutschland 1849-1871 (Frankfurt-on-Main, 1990), pp. 200-231. Siemann stresses the fact that the decisive transformation of German liberalism occurred after 1866.

- The importance of the latter point is underlined by James J. Shechan, Der deutsche Liberalismus (Munich, 1983), pp. 216-217.

' Sec Charles Tilly, Coercion, Capital, and European States (Cambridge, Mass., and Oxford, 1991).

- For an claboration of this point sec William H. Sewell jun., "Collective Violence and Collective Loyalties in France: Why the French Revolution Made a Difference", Politics and Socicty, 18 (1990), pp. 527-552.
} 
on liberalism and nineteenth-century working-class movements, can usefully be juxtaposed with Luebbert's study. Both books focus on the relationship between liberalism and the emerging labour movement, and both authors approach their subject from a comparative viewpoint. The essays in Breuilly's book deal mainly with British and German liberalism, but they are informed by a broader, European comparative perspective. Finally, Breuilly attaches far greater importance to both political culture and military politics than Luebbert does.

Breuilly's treatment of the historical preconditions of successful Lib-Lab politics is much more detailed and finely tuned than Luebbert's, but his conclusions are not substantially different. Both authors stress the importance of political factors as opposed to economic structures; both reject explanations in terms of the pace of industrialization or the structure of industry. The Liberals were able to forge successful Lib-Lab coalitions if, and only if, there existed a parliamentary regime and a strong liberal middle-class movement before the great upsurge of labour agitation in the 1880s.

Breuilly, however, pays far more attention to the contribution of socio-cultural factors to the alliance between labour and liberalism, emphasizing the importance of Protestant dissent and the broad associational culture underpinning liberal politics in Britain. He also points to the greater vigour of British civil society, where social movements and public opinion had been effective forces since the late eighteenth century.' At an earlier stage German liberalism became organized in a formal political party, but for that very reason it was far less able to articulate the broad coalition of social forces that gave the British Liberals their remarkable resilience. In Breuilly's words, "It is precisely because the ideas, organisation and sociology of British liberalism are so much harder to pin down that it enjoyed so much more success" (p. 270).

Breuilly is decidedly more accurate than Luebbert in paying attention to divisions within the working classes, especially to the problem of the labour aristocracy and, in a brilliant chapter, to the "artisan contribution" to the nineteenth-century European labour movement. His investigation of artisan political culture shows why an alliance between certain types of labour movement and liberalism could be a genuine coalition and not simply an "integration" or, worse, "co-optation" of artisans into middle-class culture and politics. ${ }^{10}$ Following the recent work of Stedman Jones and other historians, Breuilly underscores the eighteenth-century origins of artisan politics and the persistence of the older radical language of politics, positing the state and capital as external "encroachments" on the interests of labour well into the middle years of the nineteenth century.

Breuilly's treatment of German liberalism is especially valuable because he does not subscribe to the misconception that there really existed an entity called "Germany" before 1871, except of course in the various strands of the nationalist imagination. The really important difference between British and German liberalism was the lack of a clear political centre which would have enabled the liberal groupings within the different states which made up "Germany" to pursue an

- A similar argument is made by Christiane Eisenberg, "The Comparative View in Labour History", International Review of Social History, 34 (1989), pp.403-432, csp. pp. 427-428.

"See also Friedrich Lenger, "Beyond Exceptionalism: Notes on the Artisanal Phase of the Labour Movement in France, England, Germany and the United States", International Review of Social History, 36 (1991), pp. 1-23. 
effective common strategy. Rather than the internal divisions within, say, Prussian liberalism undermining the overall effectiveness of German liberalism, it was the fragmentation of the liberal movement into several regional liberalisms that accounts for the inability of the Liberals to come to terms with the issue of a "greater Germany". The infamous National-Liberalismus that split the ranks of German Liberals in the aftermath of Bismarck's 1866 victory was mainly based in the states newly annexed by Prussia in the North-German Confederation, while opposition to Bismarck remained far stronger in the old Prussian Liberal Party.

Breuilly does not deny that the German Liberals were generally more academic and theoretical than their British counterparts, and he affirms their inability, and sometimes reluctance, to build real coalitions with popular movements. But in the final analysis he attributes these failings not to the Liberals themselves, nor to the supposedly un-liberal disposition of the German bourgeoisie, but rather to the inexorable logic of state-making in Mitteleuropa.

The Liberals were caught in a situation in which they were utterly unable to control the major co-ordinates of the political process: they were forced to take sides in wars they had not initiated, and they were thereafter exposed to the trial of the sudden introduction of universal manhood suffrage. Even if they had tried, they probably could not have forged an effective Lib-Lab alliance in these unfavourable circumstances, for the elementary reason that a necessary prerequisite for such a strategy to succeed is the possession of real state power. What the working-class movement in Britain valued above all else was the Liberals' readiness to acknowledge the respectability of the working class and its institutions. Gladstonian liberalism appealed to the workers not as members of a particular social class but as citizens." The German Liberals were unable to follow that example, for the simple but extremely crucial reason that they themselves could never aspire to be full citizens, real citoyens, in Bismarck's German state.

In his concluding essay Breuilly makes the paradoxical, but probably tenable, assertion "that liberalism was much more clearly a part of bourgeois and selfconscious modernist culture in Germany than it was in either Britain or France" (p. 288). The liberal Burgertum dominated economic and cultural life, more so than the British and French middle classes did. Of course one could argue that it was somehow in the "ojective interest" of the German bourgeoisie to submit to the Bismarckian state, given the fact that the bourgeoisie are not necessarily democrats, and that law and order were valuable assets in the confrontation with an autonomous socialist movement. ${ }^{12}$ Breuilly, however, rejects this argument; in his opinion the really decisive fact was "that a key element of political modernisation involved territorial change and that could only be brought about by war between states" (p. 289). Liberalism, however, finds it very difficult to cope with war; it is predicated upon peace. This is, of course, very much to the credit of liberalism, but in the German situation it proved a fatal weakness. The wars that accompanied German unification enormously fortified the military and the bureau-

"The vital importance of this aspect of British liberal politics is highlighted in a recent study by Eugenio F. Biagini, Liberty, Retrenclment and Reform: Popular Liberalism in the Age of Gladstone, 1860-1880 (Cambridge, 1992).

${ }^{12}$ This is the main thrust of David Blackbourn and Geoff Eley's argument in The Peculiarities of German History: Bourgeois Society and Politics in Nineteenth-Century Germany (Oxford, 1984). 
cracy, institutions which, as Breuilly notes, were thoroughly modern but by no means liberal.

And so, Breuilly concludes, there was after all a German Sonderweg, for Germany was the only major European nation that combined an economically and culturally strong, modernist bourgeoisie with equally modern but non-liberal and non-parliamentary institutions possessing ultimate power in the state. Moreover, Germany was becoming a world power by 1900 , so that the peculiarities of the German political system were bound to have major international consequences.

Breuilly's argument has some broader implications. First, his emphasis on the links between war and state-formation should be placed in a European rather than a German framework. State-formation and the transformation of political regimes were international processes, and the links between the development of political regimes in different countries deserve more attention. It is, for instance, one of the major flaws of Luebbert's otherwise instructive book that he relies exclusively on a country-by-country comparison. His explanation of the rise of Fascism is severely marred by the omission of war as one of the major causes of and means to the success of the Fascists.

Secondly, both Breuilly's emphasis on war and his demonstration of the importance of the institutions of civil society point to the relevance of the experiences of the 1789-1815 period, and beyond that of the early modern age, to explain the ulterior development of political regimes in different parts of Europe. All the political actors in the nineteenth century had to operate within a number of "given" strategic, institutional and socio-cultural features of their respective societies, and these characteristics can only be explained in terms of the difference between their ancien régimes and the disparate transformations they underwent in the Napoleonic era.

To a certain extent, we are perhaps compelled to return to Barrington Moore's problematic, though necessarily not to his answers. The establishment of a closer link between the recent spate of comparative studies of the early modern period and the kind of comparative work on nineteenth-century politics produced by Luebbert and Breuilly (and many others) would probably yield interesting and rewarding results, both for our understanding of the trajectories of liberalism and for the study of the larger issue of state-formation in the nineteenth century and beyond. 